\title{
UPAYA MENINGKATKAN HASIL BELAJAR MATEMATIKA SISWA KELAS X TAV SMKN 2 PONTIANAK MELALUI MODEL PEMBELAJARAN TEAM ASSISTED INDIVIDUALIZATION ( TAI)
}

\author{
Siti Maryam \\ SMKN 2 Pontianak
}

\begin{abstract}
Abstrak
Upaya Meningkatkan Hasil Belajar Matematika Siswa Kelas X TAV SMKN 2 Pontianak Melalui Model Pembelajaran Team Assisted Individualization (TAI) . Penelitian ini bertujuan untuk mengetahui dan menganalisis apakah melalui implementasi model pembelajaran kooperatif tipe TAI dapat meningkatkan hasil belajar matematika siswa kelas X TAV SMKN 2 Pontianak pokok bahasan Trigonometri. Penelitian ini merupakan penelitian tindakan kelas yang terdiri dari dua siklus. Subyek penelitian ini adalah siswa kelas X TAV SMKN 2 Pontianak Tahun Pelajaran 2015/2016 yang berjumlah 37 siswa yang terdiri dari 17 siswa putra dan 10 siswa putri, seorang guru Matematika Kelas X TAV SMKN 2 Pontianak, dan seorang observer. Indikator keberhasilannya ditunjukkan dengan adanya peningkatan hasil belajar siswa, yaitu apabila sekurang-kurangnya $70 \%$ hasil belajar siswa kelas X TAV SMKN 2 Pontianak Tahun Pelajaran 2015/ 2016 pokok bahasan Trigonometri sudah mencapai sekurang-kurangnya 70.Pada siklus 1 rata -rata kelasnya mencapai 67.31, siswa yang tuntas sebanyak 19 anak $(51.35 \%)$ dan yang tidak tuntas sebanyak 18 anak (48.65\%) dengan nilai tertinggi 98 dan nilai terendah 45. Pada siklus 1 untuk nilai rata-rata hasil belajar yang diperoleh belum mencapai indikator yang ditetapkan, dan untuk prosentasi ketuntasan masih dibawah indikator yang ditetapkan. Pada siklus 2 rata-rata kelasnya mencapai 75, siswa yang tuntas sebanyak 31 anak (34.78\%) dan yang tidak tuntas sebanyak 6 anak (16.22\%) dengan nilai tertinggi 95 dan nilai terendah 53 Pada siklus 2 hasil belajar yang diperoleh sudah mencapai indikator yang ditetapkan.Berdasarkan hasil penelitian di atas, dapat disimpulkan bahwa melalui implementasi model pembelajaran kooperatif tipe TAI dapat meningkatkan hasil belajar siswa kelas X TAV SMKN 2 Pontianak
\end{abstract}

\section{Kata Kunci : Team Assisted Individualization ( TAI), Hasil Belajar}

\section{PENDAHULUAN}

Berdasarkan realita yang ada kebanyakan siswa SMK kurang antusias dalam menerima pelajaran Matematika, mereka lebih bersifat pasif, enggan, takut atau malu untuk mengemukakan pendapatnya. Tidak jarang siswa kurang mampu dalam mempelajari Matematika sebab Matematika dianggap sulit, menakutkan bahkan sebagian dari mereka ada yang membencinya. Matematika dianggap sebagai momok oleh mereka, hal ini menyebabkan siswa menjadi takut atau fobia terhadap Matematika

Guru Matematika yang berhasil adalah guru yang mampu mengatasi dan menyelesaikan masalah pembelajaran di kelas secara bijaksana. Sehubungan dengan itu, tentulah tidak mencukupi bagi seorang guru Matematika hanya bergantung pada strategi dan teknik yang lama dalam mengajar Matematika, tetapi harus dengan cara yang lain yang dapat menarik siswa untuk berpartisipasi secara aktif dalam proses belajar mengajar, 
karena tujuan setiap proses belajar megajar adalah diperolehnya hasil belajar yang optimal. Hal ini dapat dilakukan apabila siswa terlibat secara aktif baik fisik, mental maupun emosi. Keberhasilan proses pembelajaran merupakan hal utama yang didambakan dalam melaksanakan pendidikan di sekolah. Dalam proses pembelajaran komponen utama adalah guru dan siswa. Agar proses pembelajaran berhasil, maka guru harus membimbing siswa sedemikian rupa sehingga mereka dapat mengembangkan pengetahuannya sesuai dengan struktur pengetahuan mata pelajaran yang dipelajarinya.

Permasalahan yang Muncul Proses pembelajaran matematika pada pokok bahasan Trigonometri khususnya sub pokok bahasan aturan sinus, kosinus dan luas daerah segitiga di SMKN 2 Pontianak belum memperoleh hasil yang memuaskan, dengan nilai rata-rata 63 untuk tahun pelajaran 2015/2016 dengan KKM 70 dan jumlah ketuntasan siswa 18 dari 37 siswa. Masalah ini membuat guru kesulitan dalam memilih model pembelajaran yang tepat untuk menyampaikan materi. Agar dalam pelaksanaan pembelajaran Matematika tidak membosankan sehingga siswa senang dalam pembelajaran Matematika maka dalam pelaksanaannya dapat menerapkan berbagai strategi. Salah satunya adalah melalui penggunaan model pembelajaran yang tepat dalam proses belajar mengajar. Model pembelajaran yang dipilih diharapkan

mampu mengembangkan dan meningkatkan kompetensi, kreativitas, kemandirian, kerjasama (cooperative), kepemimpinan, toleransi dan kecakapan hidup siswa. Model pembelajaran yang sesuai dengan maksud di atas, salah satunya adalah model pembelajaran kooperatif tipe TAI (Team Assisted Individualization)
Model pembelajaran TAI merupakan model pembelajaran yang mempunyai strategi pembelajaran penerapan bimbingan antar teman. Dalam pembelajaran ini siswa diberi LKS untuk dikerjakan secara kelompok sehingga siswa dengan mudah dapat memahami konsep materi, yaitu Trigonometri. Melalui model pembelajaran TAI siswa diajak belajar mandiri, dilatih untuk mengoptimalkan

kemampuannya dalam menyerap informasi ilmiah yang dicari, dilatih untuk menjelaskan temuannya kepada pihak lain dan dilatih untuk memecahkan masalah. Jadi melalui model pembelajaran ini siswa diajak berpikir dan memahami materi tidak hanya mendengar, menerima dan mengingat-ingat saja.

Hasil belajar merupakan perubahan yang diperoleh pembelajar setelah mengalami aktivitas belajar (Anni, 2006: 5). Perolehan aspek-aspek perubahan perilaku tersebut tergantung pada apa yang dipelajari oleh pembelajar. Oleh karena itu apabila pembelajar mempelajari pengetahuan tentang konsep, maka perubahan perilaku yang diperoleh adalah berupa penguasaan konsep. Dalam pembelajaran, perubahan perilaku yang harus dicapai oleh pembelajar setelah

melaksanakan aktivitas belajar dirumuskan dalam tujuan pembelajaran (Anni, 2006: 5).

Faktor-faktor yang menentukan pencapaian hasil belajar (Dalyono, 2005:55) adalah sebagai berikut.

1. Faktor internal (yang berasal dari dalam diri)

a. Kesehatan

Kesehatan jasmani dan rohani sangat besarpengaruhnya terhadap kemampuan belajar. Bila seseorang selalu tidak sehat, sakit kepala, demam, pilek, batuk dan sebagainya, dapat mengakibatkan tidak bergairah untuk belajar.

b. Minat dan Motivasi 
Sebagaimana halnya dengan intelegensi dan bakat maka minat dan motivasi adalah dua aspek psikis yang juga besar pengaruhnya terhadap pencapaian prestasi belajar.

c. Cara Belajar

Cara belajar seseorang juga mempengaruhi pencapaian hasil belajarnya. Belajar tanpa memperhatikan teknik dan faktor fisiologis, psikologis, dan ilmu kesehatan, akan memperoleh hasil yang kurang memuaskan.

2. Faktor eksternal (yang berasal dari luar diri)

a. Keluarga

Keluarga adalah ayah, ibu, dan anakanak serta famili yang menjadi penghuni rumah. Faktor orang tua sangat besar pengaruhnya terhadap keberhasilan anak dalam belajar.

b. Sekolah

Keadaan sekolah tempat belajar turut, mempengaruhi tingkat keberhasilan belajar. Kualitas guru, metode mengajarnya kesesuaian kurikulum dengan kemampuan anak, keadaan fasilitas/ perlengkapan di sekolah, keadaan ruangan, jumlah murid per kelas, pelaksanaan tata tertib sekolah, dan sebagainya, semua itu turut mempengaruhi keberhasilan belajar anak.

c. Masyarakat

Keadaan masyarakat juga menentukan prestasi belajar. Bila di sekitar tempat tinggal keadaan masyarakatnya terdiri dari orang-orang yang berpendidikan, terutama anak-anaknya rata-rata bersekolah tinggi dan moralnya baik, hal ini akan mendorong anak lebih giat belajar. Tetapi sebaliknya, apabila tinggal di lingkungan banyak anakanak yang nakal, tidak bersekolah dan pengangguran, hal ini akan mengurangi semangat belajar atau dapat dikatakan tidak menunjang sehingga motivasi belajar berkurang.

d. Lingkungan sekitar
Keadaan lingkungan tempat tinggal, juga sangat penting dalam mempengaruhi prestasi belajar. Keadaan lingkungan, bangunan rumah, suasana sekitar, keadaan lalu lintas, iklim dan sebagain

\section{Model pembelajaran Team Assisted Individualization (TAI)}

(Ibrahim, Muslimin. 2000 : 17 )Model pembelajaran kooperatif tipe $T A I$ memiliki 8 (delapan) komponen, yaitu

a. Teams, yaitu pembentukan kelompok heterogen yang terdiri atas 4 sampai 6 siswa.

b. Placement test, yakni pemberian pre-tes kepada siswa atau melihat rata-rata nilai harian siswa agar guru mengetahui kelemahan siswa dalam bidang tertentu.

c. Student Creative, melaksanakan tugas dalam suatu kelompok dengan menciptakan situasi dimana keberhasilan individu ditentukan atau dipengaruhi oleh keberhasilan kelompoknya.

d. Team Study, yaitu tahapan tindakan belajar yang harus dilaksanakan oleh kelompok dan guru memberikan bantuan secara individual kepada siswa yang membutuhkannya.

e. Team Scores and Team Recognition, yaitu pemberian skor terhadap hasil kerja kelompok dan memberikan criteria penghargaan terhadap kelompok yang berhasil secara cemerang dan kelompok yang dipandang kurang berhasil dalam menyelesaikan tugas.

f. Teaching Group, yakni pemberian materi secara singkat dari guru menjelang pemberian tugas kelompok.

g. Facts Test, yaitu pelaksanaan tes-tes kecil berdasarkan fakta yang diperoleh siswa.

h. Whole Class Units, yaitu pemberian materi oleh guru kembali di akhir waktu pembelajaran dengan strategi 
pemecahan masalah keaktifan, kemandirian dan keterampilan siswa dapat dikembangkan dan akhirnya pemahaman konsep yang diperoleh dapat berkembang secara efektif.

\section{Langkah-langkah Pembelajaran Kooperatif} Tipe TAI

Adapun Langkah-langkah dari model pembelajaran kooperatif tipe TAI adalah sebagai berikut:

1. Guru memberikan tugas kepada siswa untuk mempelajari materi pembelajaran secara individual yang sudah dipersiapkan oleh guru.

2. Guru memberikan kuis secara individual kepada siswa untuk mendapatkan skor dasar atau skor awal.

3. Guru membentuk beberapa kelompok. Setiap kelompok terdiri dari 4-5 siswa dengan kemampuan yang berbeda-beda baik tingkat kemampuan (tinggi, sedang dan rendah). Jika mungkin anggota kelompok berasal dari ras, budaya, suku yang berbeda serta kesetaraan jender.

4. Hasil belajar siswa secara individual didiskusikan dalam kelompok. Dalam diskusi kelompok, setiap anggota kelompok saling memeriksa jawaban teman satu kelompok.

5. Guru memfasilitasi siswa dalam membuat rangkuman, mengarahkan, dan memberikan penegasan pada materi pembelajaran yang telah dipelajari.

6. Guru memberikan kuis kepada siswa secara individual.

7. Guru memberi penghargaan pada kelompok berdasarkan perolehan nilai peningkatan hasil belajar individual dari skor dasar ke skor kuis berikutny

\section{Indikator Keberhasilan}

Tolok ukur keberhasilan dalam penelitian ini adalah apabila sekurang-kurangnya $70 \%$ hasil belajar siswa kelas X TAV SMKN 2 Pontianak Tahun Pelajaran 2015/2016 dan kkm pokok bahasan Trigonometri sudah mencapai sekurang-kurangnya 70

\section{Lokasi dan Waktu Penelitian}

Penelitian ini merupakan penelitian tindakan kelas yang dilaksanakan di SMKN 2 Pontianak yang beralamatkan di Kalan Khatulistiwa 215 Pontianak terdiri dari dua siklus dan masing masing siklus terdiri dari dua pertemuan siklus pertama pertemuan pertama rabu tanggal 23 maret 2016 dan pertemuan kedua selasa tanggal 12 april 2016. Dan siklus kedua pertemuan pertama selasa tanggal 13 april 2016 dan pertemuan kedua rabu tanggal 20 april 2016.

\section{Subjek Penelitian}

Subjek penelitian ini adalah siswa kelas $\mathrm{X}$ TAV SMKN 2 Pontianak Tahun Pelajaran 2015/2016 yang berjumlah 37 siswa yang terdiri dari 17 siswa putra dan 10 siswa putri, seorang guru Matematika Kelas X TAV SMKN 2 Pontianak, dan seorang observer

\section{Prosedur Penelitian}

Penelitian ini merupakan Penelitian Tindakan Kelas (PTK) yang dilaksanakan dalam 2 (dua) siklus, masing-masing siklus dilaksanakan dalam 4 (empat) tahap, yaitu perencanaan, tindakan, pengamatan, dan refleksi.

\section{Pembahasan}

\section{Perencanaan}

Pada perencanaan Penelitian Tindakan Kelas ini Peneliti dibantu oleh seorang observer yaitu teman sejawat yang mengajar matematika Bapak Rudi S.Pd. adapun tahapan perencanaan sebagai berikut

1) Merancang Rencana Pelaksanaan Pembelajaran (RPP) menggunakan implementasi model pembelajaran kooperatif tipe TAI dengan materi aturan sinus dan kosinus.. 
2) Merancang pembelajaran dengan membentuk kelompok belajar siswa, tiap kelompok beranggotakan 45 orang siswa. Kelompok dibuat dengan tingkat

kepandaian dengan mempertimbangkan keharmonisan kerja kelompok.

3) Merancang lembar observasi untuk guru, siswa, dan aktivitas diskusi kelompok.

4) Merancang angket tentang tanggapan siswa terhadap pembelajaran matematika melalui implementasi model pembelajaran kooperatif tipe TAI

5) Merancang LKS dan kunci jawaban dengan materi aturan sinus dan kosinus.

6) Merancang kuis dan kunci jawaban dengan materi aturan sinus dan kosinus.

7) Merancang soal tes formatif siklus 1 dan kunci jawabannya dengan materi aturan sinus dan kosinus.

8) Menyiapkan sarana dan prasarana yang diperlukan dalam pembelajaran

9)

\section{Pelaksanaan}

Pelaksanaan pembelajaran pada siklus 1 terdiri dari 2 (dua) pertemuan, yaituPertemuan pertama pada siklus 1 dilaksanakan pada hari Jum'at tanggal 23 Maret 2016 selama 2 x 45 menit, yaitu jam ke3 dan ke4. Pertemuan pertama pada siklus 1 berisi penyampaian materi aturan sinus dan kosinus kemudian dilanjutkan dengan pemberian LKS untuk didiskusikan pada kelompoknya masing-masing Pertemuan kedua pada siklus 1 dilaksanakan pada hari Kamis tanggal 12 April 2016 selama 2 x 45 menit, yaitu jam ke7 dan ke8. Pertemuan kedua pada siklus 1 berisi pemberian tes formatif selama 90 menit.

\section{Hasil Siklus I}

Dari pelaksanaan siklus 1, diperoleh berbagai data yaitu data mengenai hasil belajar siswa, data mengenai hasil observasi kinerja guru, data mengenai kinerja siswa, data mengenai aktivitas diskusi kelompok, dan data tentang hasil angket tanggapan siswa terhadap pembelajaran.

\section{Hasil belajar siswa (tes)}

Setelah dilakukan analisis data hasil tes siklus 1 dengan sub pokok bahasan aturan sinus dan kosinus, diperoleh nilai rata-rata siswa sebesar 67.31, siswa yang tuntas sebanyak 19 anak (51.35\%), siswa yang tidak tuntas sebanyak 18 anak (48.65\%) dengan nilai tertinggi 98 dan nilai terendah 45. Berdasarkan hasil tes pada siklus 1, nilai rata-rata hasil belajar yang dicapai siswa adalah 67.31 dengan prosentasi 51.28\%, untuk nilai rata-rata hasil belajar yang dicapai sudah mencapai indikator keberhasilan yang ditetapkan tetapi untuk prosentasi masih jauh dibawah indikator keberhasilan yang ditetapkan.

\section{Pengamatan (observasi)}

Pengamatan atau observasi yang dilakukan meliputi observasi aktivitas diskusi kelompok, kinerja siswa, dan kinerja guru selama pembelajaran dalam pengamatan observer melihat ketidak berhasilan siklus pertama diakibatkan beberapa faktor diantaranya adalah sebagai berikut.

a. Siswa belum memahami peran dan tugasnya dalam bekerja kelompok karena belum terbiasa dengan model pembelajaran yang diterapkan.

b. Interaksi antar siswa belum berjalan dengan baik karena siswa belum terbiasa untuk menyampaikan pendapatnya kepada sesama teman lainnya dalam menyelesaikan masalah.

c. Adanya siswa yang pasif dan menggantungkan permasalahan yang dihadapi kepada kelompoknya.

d. Dalam diskusi kelompok hanya didominasi oleh siswa yang pandai saja

e. Pada saat penyajian hasil karya kelompok hanya beberapa kelompok saja yang 
menyajikan hasil karya kelompoknya karena waktu yang tidak memungkinkan.

f. Guru belum bisa mengorganisasikan waktu dengan baik, karena waktu untuk mengerjakan LKS terlalu lama sehingga waktu untuk presentasi hasil karya kelompok terbatas.

g. Guru dalam memberikan bimbingan tidak merata, guru hanya memberikan bimbingan pada kelompok yang aktif bertanya saja.

\section{Refleksi}

Uraian di atas menyatakan bahwa pada siklus 1 indikator keberhasilan belum tercapai. Oleh karena itu perlu adanya suatu tindakan pada siklus 2 agar hasil belajar siswa dapat ditingkatkan dan mencapai indikator keberhasilan yang ditetapkan

1. Setiap kelompok terdiri dari 4-5 siswa dengan kemampuan yang berbeda-beda baik tingkat kemampuan (tinggi, sedang dan rendah)

2. Guru mengorganisasikan waktu dengan baik, karena waktu untuk mengerjakan LKS terlalu lama sehingga waktu untuk presentasi hasil karya kelompok terbatas.

3. Guru dalam memberikan bimbingan merata, guru dan menjelaskan kembali penggunaan TAI pada siswa

4. Guru memberi penghargaan pada kelompok berdasarkan perolehan nilai peningkatan .

\section{Siklus 2}

\section{Perencanaan}

Sesuai dengan refleksi aktivitas diskusi kelompok, kinerja siswa, dan kinerja guru pada siklus 1 diatas, maka pada siklus 2 dilaksanakan sebagai berikut

1) Guru harus dapat mengorganisasikan waktu dalam pembelajaran dengan baik sehingga semua tahap dalam pembelajaran dapat dilaksanakan dengan baik dan optimal.

2) Merancang Rencana Pelaksanaan Pembelajaran (RPP_ menggunakan implementasi model pembelajaran kooperatif tipe TAI dengan materi luas daaerah segitiga.

3) Merancang pembelajaran dengan membentuk kelompok belajar siswa, tiap kelompok beranggotakan 4-5 orang siswa. Kelompok dibuat dengan tingkat kepandaian dengan mempertimbangkan keharmonisan kerja kelompok.

4) Merancang lembar observasi untuk guru, siswa, dan aktivitas diskusi kelompok.

5) Merancangang keterangan tentang tanggapan siswa terhadap pembelajaran Matematika melalui implementasi model pembelajaran kooperatif tipe TAI.

6) Merancang LKS dan kunci jawaban dengan materi luas daerah segitiga.

7) Merancang kuis dan kunci jawaban dengan materi luas daerah segitiga.

8) Merancang soal tes formatif siklus 1 dan kunci jawabannya dengan materi luas daerah segitiga.

9) Menyiapkan sarana dan prasarana yang diperlukan dalam pembelajaran.

\section{Pelaksanaan}

Pertemuan pertama pada siklus 2 dilaksanakan pada hari Jum'at tanggal 13 April 2016 selama 2 x 45 menit, yaitu jam ke 3 dan ke 4. Pertemuan pertama pada siklus 2 berisi penyampaian materi luas daerah segitiga kemudian dilanjutkan dengan pemberian LKS untuk didiskusikan pada kelompoknya masing Pertemuan kedua pada siklus 2 dilaksanakan pada hari Jum'at tanggal 20 April 2016 selama $2 \times 45$ menit, yaitu jam ke_3 dan ke_4. Pertemuan kedua pada siklus 2 berisi pemberian tes formatif selama 90 menit

\section{Hasil belajar siswa (tes) siklus II}

Setelah dilakukan analisis data hasil tes siklus 2 dengan sub pokok bahasan luas daerah segitiga, diperoleh nilai rata-rata siswa sebesar 75, siswa yang tuntas sebanyak 31 anak (83.78\%), siswa yang tidak tuntas sebanyak 6 anak (16.22\%) 
dengan nilai tertinggi 95 dan nilai terendah 53 dari hasil diatas menujukkan bahwa ketuntasan siswa $84.62 \%$ telah melampaui indicator Keberhasilan PTK yaitu $70 \%$ dan nilai rata rata 75 telah melampaui KKM yang diinginkan yaitu 70 sehingga penelitian tindakan kelas ini tidak perlu dilanjutkan dan dari data diatas mebuktikan bahwa model pembelajaran koopertaif tipe TAI dapat meningkatkan hasil belajar siswa kelas $\mathrm{X}$ TAV SMKN 2 pokok bahasan Tigonometri

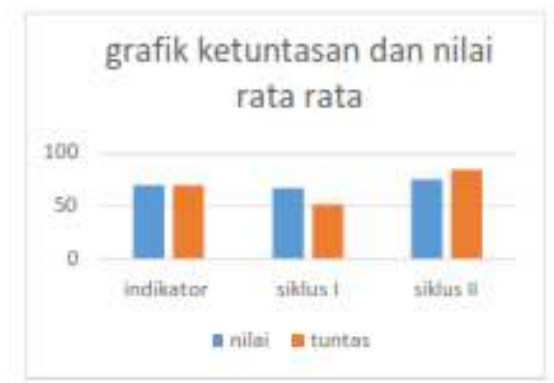

Gambar 1. Ketuntasan dan Nilai Rata-Rata
Siswa

\section{Pengamatan ( Observasi)}

Pengamatan atau observasi yang dilakukan meliputi observasi aktivitas diskusi kelompok, kinerja siswa, dan kinerja guru selama pembelajaran berlangsung. Berjalan dengan baik.

\section{Refleksi}

Dari refleksi diatas secara garis besar penelitian tindakan kelas telah berhasil terbukti Setelah dilakukan analisis data hasil tes siklus 2 dengan sub pokok bahasan luas daerah segitiga, diperoleh nilai rata-rata siswa sebesar 75 , siswa yang tuntas sebanyak 31 anak $(83.78 \%)$, siswa yang tidak tuntas sebanyak 6 anak $(16.22 \%)$ dengan nilai tertinggi 95 dan nilai terendah 53 dari hasil diatas menujukkan bahwa ketuntasan siswa $84.62 \%$ telah melampaui indicator Keberhasilan PTK yaitu $70 \%$ dan nilai rata rata 75 telah melampaui KKM yang diinginkan yaitu70 sehingga penelitian tindakan kelas ini tidak perlu dilanjutkan dan dari data diatas mebuktikan bahwa model pembelajaran koopertaif tipe TAI dapat.

\section{KESIMPULAN DAN SARAN Kesimpulan}

Berdasarkan hasil penelitian dan pembahasan yang disajikan dalam Bab IV maka dapat ditarik simpulan bahwa melalui implementasi model pembelajaran kooperatif tipe $T A I$ dapat meningkatkan hasil belajar siswa kelas $\mathrm{X}$ TAV SMKN 2 Pontianak pokok bahasan Trigonometri terbukti dengan meningkatnya ketuntasan serta hasil belajar siswa Pada siklus 1 rata -rata kelasnya mencapai 67.31, siswa yang tuntas sebanyak 19 anak (51.35\%) dan yang tidak tuntas sebanyak 18 anak (48.65\%) dengan nilai tertinggi 98 dan nilai terendah 45. Pada siklus 1 untuk nilai ratarata hasil belajar yang diperoleh belum mencapai indikator yang ditetapkan, dan untuk prosentasi ketuntasan masih dibawah indikator yang ditetapkan. Pada siklus 2 ratarata kelasnya mencapai 75 , siswa yang tuntas sebanyak 31 anak $(34.78 \%)$ dan yang tidak tuntas sebanyak 6 anak (16.22\%) dengan nilai tertinggi 95 dan nilai terendah 53

\section{Saran}

Berdasarkan simpulan disarankan pada guru mata pelajaran Matematika agar menerapkan model pembelajaran kooperatif tipe TAI pada pokok bahasan Trigonometri yang dapat meningkatkan hasil belajar Matematika siswa.

\section{DAFTAR RUJUKAN}

Anni. 2006. Psikologi Belajar. Jakarta: PT Rineka Cipta.

Arikunto, Suharsimi. 2002. Prosedur Penelitian. Jakarta: PT Rineka Cipta.

Baedowi. 2016. Kebijakan dan Pengembangan Kurikulum. Jakarta: DPN Staf Ahli Mendiknas Bidang PKMP. 
Bahri dan Aswan. 2002. Strategi Belajar Mengajar. Jakarta: PT Rineka Cipta.

Dalyono. 2005. Psikologi Pendidikan. Jakarta: PT Rineka Cipta.

Dimyanti dan Mudjiono. 2002. Belajar dan Pembelajaran. Jakarta: PT Rineka Cipta.
Ibrahim, Muslimin. 2000. Pembelajaran Kooperatif. Surabaya: Unesa University Press

Noormandiri. 2004. Buku Pelajaran Matematika SMK untuk Kelas X. Jakarta:Erlangga 